\title{
Optimum fin spacing of rectangular fins on a vertical base in free convection heat transfer
}

\author{
B. Yazicioğlu $\cdot$ H. Yüncü
}

Published online: 18 August 2007

(C) Springer-Verlag 2007

Erratum to: Heat Mass Transfer

DOI 10.1007/s00231-006-0207-6

The original version of this article unfortunately contained a mistake.

The presentation of Eqs. (19) and (20) was incorrect. The correct versions are given below.

$\frac{s_{\mathrm{opt}}}{L}=3.53 R a_{L}^{-1 / 4}$

$\left(\dot{Q}_{\mathrm{c}_{\max }}=\left(\dot{Q}_{0}\right)_{\mathrm{c}}\right)+0.125 R a_{L}^{1 / 2} k H \Delta T\left(\frac{W}{L}\right)$

The online version of the original article can be found under doi:10.1007/s00231-006-0207-6.

B. Yazicioğlu $\cdot$ H. Yüncü $(\square)$ Department of Mechanical Engineering, Middle East Technical University,

Ankara 06531, Turkey

e-mail: hafit@metu.edu.tr 